\title{
ДІЯЛЬНІСТЬ УПОВНОВАЖЕНИХ ТА АКТИВІСТІВ У ХОДІ ОРГАНІЗАЦІЇ ГОЛОДОМОРУ-ГЕНОЦИДУ НА КИЇВЩИНІ ТА ЧЕРНІГІВЩИНІ У 1932-1933 РОКАХ
}

Анотація: Мета дослідження: аналіз прикладів боротьби активістів та уповноважених 3 хлібозаготівель 3 «куркульським елементом» під час Голодомору-геноциду 1932-1933 рр. у Київській і Чернігівській областях, використовуючи матеріали районної періодики тих років. Методологія грунтується на принципах історизму, об'єктивності та системності. Використано методику джерелознавчого аналізу періодичної преси, а також загальноісторичні методи: історикогенетичний, ретроспективний, історико-типологічний.

Наукова новизна. На основі широкого спектру матеріалів періодики обірунтовано деструктивну роль активістів та уповноважених у боротьбі з «куркульським елементом» при хлібозаготівлях, що призвело до Голодомору-геноциду у вказаних регіонах.

Висновки. Зазначено, що одним із головних, іяк виявилось доволі ефективних, інструментів політтехнології комуністичного режиму були групи сільських «активістів», виконавиів та уповноважених, які вдавалися до цілого арсеналу методів у боротьбі 3 «куркулями» та "куркульським елементом", виконуючи злочинні норми хлібозаготівлі. Якщо 3 "куркулями» ситуація була зрозумілою, - абсолютно штучний образ ворога, який накладався у межах масової пропагандистської кампанії на селян-господарників, то куди иікавішою є ситуація з так званим «куркульським елементом», до якого комуністична влада зараховувала зрадників, саботажників $i$ дезертирів з числа сільського активу, що відмовлялися виконувати злочинні норми хлібозаготівель. Їх ідентифікували як «полигачів» $і$ посібників «куркулів», які підлягають громадському осуду, вилученню з партії та засудженню на різні терміни позбавлення волі в залежності від ступеня вини. З'ясовано, що комуністична влада, використовуючи районну періодику, прямо вказувала та виявляла подібних «куркульських агентів з партійними квитками», на базі методу акцентування на персональних і локальних факторах, протиставляючи їм «ударні» елементи, до яких відносили окремі постаті, бригади та села, які виконували та перевиконували хлібозаготівлі.

Ключові слова: Голодомор-геноцид 1932-1933рр., районна періодика, активісти, уповноважені, хлібозаготівлі

Останнім часом дослідники теми Голодомору-геноциду 1932-1933 рр. звертаються до мікроісторичного аспекту цієі проблеми, намагаючись розгледіти окремих людей, конкретні їхні дії та вчинки. На тлі суцільної колективізації, перебігу хлібозаготівлі, масової загибелі селян від голоду вчені почали досліджувати діяльність сільських активістів, які

\footnotetext{
${ }^{*}$ Стасюк Олеся Олександрівна - кандидат історичних наук, Генеральний директор Національного музею Голодомору-геноциду, заслужений працівник культури України (Київ, Україна); ORCID: https://orcid.org/0000-0002-9527-982X; e-mail: olesia.stasiuk@gmail.com
} 
стали інструментом знищення «українського дрібнобуржуазного селянства». Вони виконували всі накази московського керівництва, демонструючи нечувану жорстокість під час реалізації хлібозаготівельного плану, по суті, знищуючи селянські господарства, підриваючи основу потенціального спротиву комуністичному режиму.

Вдаючись до цілого арсеналу методів (відвертий грабунок майна, побиття, тортури, гвалтування, «марширування», погрози, ошуканство тощо), активісти поглиблювати розкол між селянином-«пролетарієм» і селянином-господарником, прагнучи усіляко відмежуватися від останнього та дискредитувати будь-які його дії, прислужуючись у такий спосіб радянській владі. Це особливо помітно, якщо гортати сторінки тодішньої районної преси УСРР, де всюди наголошувалося на важливості хлібозаготівлі, незмінності курсу на виконання та перевиконання плану. Натомість осіб, які, на думку керівників партійнорадянського апарату, перешкоджали цьому, або ж гальмували хлібозаготівлі, підлягали негайному покаранню як «куркульські агенти», «опортуністи» та «дезертири». Саме тому, звернення до цього історичного джерела стало важливим аспектом у розкритті злочинних дій районних уповноважених і сільських виконавців, а також природи «більшовицького активізму» як інструменту руйнації українського села.

Для зрозуміння причини походження «більшовицького активізму» і появи його носіїв, варто звернутися до проблеми трансформації способу життя й образу українського селянина в умовах суцільної колективізації та соціальної інженерії. Ці наукові аспекти описані у працях В. Марочка ${ }^{1}$, Н. Романець ${ }^{2}$, Р. Подкура ${ }^{3}$, С. Кульчицького ${ }^{4}$ й ін. Спланована «пролетаризація» селянства, по суті, розколола останне, деформуючи соціальні та морально-психологічні засади його існування, породивши в абсолютно штучний спосіб особливу групу людей на службі у комуністичного режиму, т. зв. активістів та уповноважених. На це звернули увагу історики В. Васильєв ${ }^{5}$, С. Дровозюк ${ }^{6}$, С. Маркова ${ }^{7}$, М. Лазарович ${ }^{8}$ та ін. Вони акцентували дослідницьку увагу на появі цих груп як на

\footnotetext{
${ }^{1}$ Марочко В. Голодомор 1932-1933 рр. Київ, 2007. 62 с.; Марочко В., Мовчан О. Голодомор 1932-1933 років в Україні: Хроніка. Київ: Вид. дім «Києво-Могилянська академія», 2008. 294 с.

${ }^{2}$ Романець Н.Р. Репресивна політика радянської влади в українському селі (1925-1939): монографія. Кривий Ріг: Вид. Р.А. Козлов, 2014. 456 с.

${ }^{3}$ Колективізація 1930-х рр. очима співробітників органів державної безпеки // Історія України: Маловідомі імена, події, факти: Зб. наук. праць на пошану, акад. НАН України П.Т. Тронька. Київ: Ін-т історії України НАН України, 2005. Вип. 30. С. 136-151.

${ }^{4}$ Кульчицький С.В. Голод-геноцид 1932-1933 рр. в Україні. Київ, 2006. 256 с.; Кульчицький С.В. Голодомор 1932-1933 рр. як геноцид: труднощі усвідомлення. Київ: Наш час, 2008. 424 с.

${ }_{5}^{5}$ Васильєв В., Віола Л. Колективізація і селянський опір на Україні (листопад 1929 - березень 1930 рр.). Вінниця: Логос, 1997. 536 с.

${ }^{6}$ Дровозюк С. Соціально-психологічний портрет сільського «активіста» 20-30-х рр. в українській історіографії // Проблеми історії України: факти, судження, пошуки. 2003. № 9. С. 360-372; Дровозюк C.I. Поведінка сільських активістів під час суцільної колективізації та голодомору українського народу (1932-1933рр.) // Історія України. Маловідомі імена, події, факти. 2007. Вип. 34. С. 67-79.

${ }^{7}$ Маркова С.В. Голодомор 1932-1933 років на Поділлі: Монографія. Київ: МАУП, 2003. 116 с. Маркова С. Насилля комуністичного режиму в Україні. Пролонговані наслідки і латентні складові Голодомору 19321933 рр.: навчально-методичний посібник. Хмельницький: Видавець ФОП Цюпак А.А., 2019. 44 с.

8 Лазарович М.В. І було пекло на землі... Голодомор 1932-1933 років в Україні: передумови, механізми здійснення, наслідки: монографія. Тернопіль: Джура, 2008. 620 с.; Лазарович М.В., Николин М.М. Не погасне біль Голодомору. Тернопіль: Новий колір, 2007. 224 с.
} 
показовому прикладі виродження та деградації українського села внаслідок більшовицької «революції зверху» і, що головне, на використанні їх як карального інструменту реалізації Голодомору-геноциду 1932-1933 рр. Поряд з тим на сьогодні багато аспектів злочинної діяльності уповноважених і сільських активістів залишаються малодослідженими та потребують подальшого грунтовного наукового аналізу, що й спонукало автора звернутися до цієї проблематики.

Метою статmі є аналіз прикладів боротьби активістів та уповноважених 3 хлібозаготівлі з «куркульським елементом» під час Голодомору-геноциду 1932-1933 рр. у Київській і Чернігівській областях, використовуючи матеріали районної періодики тих років.

Визначивши пріоритетним напрямом розвитку сільського господарства ліквідацію одноосібного господарювання, створення колективного власника землі та колективного виробника сільськогосподарської продукції, вище політичне керівництво СРСР на чолі 3 Й. Сталіним доклало великих зусиль для поглиблення конфлікту між «бідняками» та «заможними»/«багатими». Йдеться переважно про застосування фіскальних інструментів, коли податковий тиск на «заможні» групи збільшувався, а «бідняків» звільняли від податків. Водночас формувалася громадської думки про важливість хлібозаготівлі і шкідливість «куркулів-експлуататорів», які становили загрозу сталінському проекту колгоспного будівництва. Для дискредитації, розкуркулення та депортації «куркулів» різко активувалося протистояння в українському селі, до якої окрім членів сільради та правління колгоспу, що уособлювали «радянську владу на селі», були долучені активісти й уповноважені.

В основному актив формували із сільської інтелігенції (вчителі та працівники культурно-просвітницьких організацій), молоді та бідноти. Вони не обмежували себе у виборі способів і прийомів під час конфіскації «куркульського майна» та методів покарання й притягнення до відповідальності «куркулів», які, начебто, протидіяли виконанню хлібозаготівельних планів.

У статті «Центр масової роботи - на кутках» йшлося про уповноважених 3 хлібозаготівлі, які безвідповідально ставилися до виконання планів, а також на «злісних зривників» хлібозаготівлі, що не виконували своїх контрактаційних зобов'язань. Автор, завершуючи статтю, зазначав: «Нещадним натиском на твердоздаванців куркулів, побойовому розгорнувши масово-роз'яснювальну роботу серед одноосібників-контрактантів провід сільради мусить добитися рішучого зламу в хлібозаготівлі й виконати протягом найближчих днів на 100 відс[отків] хлібне завдання по одноосібному сектору» ${ }^{9}$. У замітці «Передовики беруть на буксир відсталих» розповідалося про одноосібників, які після виконання свого плану почали брати участь у конфіскаційних заходах стосовно інших селян, неспроможних виконати хлібозаготівлі.

Кореспонденти газети постійно закликали до жорстких заходів стосовно тих осіб, які намагалися знизити плани чи доводили відсутність хліба у селян. Так, у замітці «Потурають нездатникам хліба» зазначено: «Треба рішуче припините будь-яке потурання і поблажливе ставлення до зривників хлібозаготівлі. Всі організації, весь актив села [Глибічка] повинні організувати маси на виконання хлібозаготівельного плану» ${ }^{10}$.

У газеті «Шлях колгоспника» (Богуслав) міститься чимало заміток, на кшталт

\footnotetext{
${ }^{9}$ Центр масової роботи на кутках // Радянська нива (Біла Церква). 1932. № 124. С. 2.

${ }^{10}$ Потурають нездатникам хліба // Радянська нива (Біла Церква). 1932. № 140. С. 2.
} 
«Відкинути такий метод масової роботи», «Притягнути до права вчителя Поліщука», «Вогонь на перекрутників настанов партії», «Покарати Гогулю та Замирайла» та «Очистити хлібозаготівельні бригади», де розглядаються різні ситуації 3 учасниками хлібозаготівельних бригад, сільським активом й головами сільрад ${ }^{11}$. Подібного змісту замітки зустрічаємо й у газеті «Соціялістична перемога» (Канів) ${ }^{12}$.

На шпальтах «Шляху колгоспника» також знаходимо чимало прикладів небажання працювати чи навіть втечі 3 хлібозаготівельних буксирних бригад. Про це йдеться у замітках «Дезертирів притягнути до права», «Вигнати Бузника 3 бригади», «За перекручування настанов партії притягти до відповідальності», «Вигнати 3 колгоспу куркульського агента», «Баранєпільські комунари по-більшовицькому поставились до боротьби за хліб», «Вигнати куркульського агента 3 колгоспу та бригади», «Очистити бригади від куркульських прихвоснів» ${ }^{13}$. Автори подібних заміток не лише начіплювали різні «контрреволюційні» ярлики на таких осіб, а й закликали їхнього жорсткого покарання за відмову брати участь у пограбуванні селянських господарств.

Про обшуки, вилучення майна та знущання над селянами з боку активістів у процесі виконання хлібозаготівлі йшлося у наступних замітках цієї ж газети: «За перекручування настанов партії притягти до відповідальності», «Нагнати Салату та Канівченка 3 бригад», «Розгромити демобілізаційні настрої», «Негайно віддати до суду куркульських агентів» ${ }^{14}$.

Рівень цинізму уповноважених добре прослідковується на прикладі статті «Притягнути до права куркульських полигачів» у газеті «Шлях колгоспника»: «Так, 26 вересня, коли хлібозаготівна бригада, що її організовував голова колгоспу Самчинський, пішла зняти хліб у твердоздавця Онищенка, то Буценко й Коваль утекли з бригади. Буценко одверто заявляє: “Як же у нього брати хліб, коли він плаче, що зостанеться голодний”. Куркульський агент повірив крокодилячим сльозам куркуля, а зовсім не зважає на те, що хліба чекають робітники промисловості, Червона армія» ${ }^{15}$.

Якщо до «куркульських полигачів» і «дезертирів хлібозаготівельного фронту» вживалися жорсткі заходи, то активних учасників буксирних і хлібозаготівельних бригад активно нагороджували. Про це постійно повідомлялося у місцевій пресі ${ }^{16}$.

Також на сторінках газети «Колгоспник Рокитнянщини» простежується

\footnotetext{
${ }^{11}$ Відкинути такий метод масової роботи; Притягнути до права вчителя Поліщука; Вогонь на перекрутників настанов партії; Покарати Гогулю та Замирайла; Очистити хлібозаготівельні бригади // Шлях колгоспника (Богуслав). 1932. № 12. С. 1-2.

${ }^{12}$ Усунути від хлібозаготівлі опортуністів; Розбити вщент куркульсько-опортуністичні настрої в хлібозаготівлі; Буксирники - п'яниці // Соціялістична перемога (Канів). 1932. 3 лютого, № 12. С. 1.

${ }^{13}$ Дезертирів притягнути до права; Вигнати Бузника з бригади // Шлях колгоспника (Богуслав). 1932. № 15; Баранєпільські комунари по-більшовицькому поставились до боротьби за хліб; Вигнати куркульського агента 3 колгоспу та бригади; Очистити бригади від куркульських прихвоснів // Шлях колгоспника (Богуслав). 1932. № 17.

${ }^{14}$ За перекручування настанов партії притягти до відповідальності; Вигнати з колгоспу куркульського агента; Нагнати Салату та Канівченка з бригад // Шлях колгоспника (Богуслав). 1932. 17 лютого, № 22. С. 1; Розгромити демобілізаційні настрої; Негайно віддати до суду куркульських агентів // Шлях колгоспника (Богуслав). 1932. 18 лютого, № 23. С. 1.

${ }^{15}$ Притягнути до права куркульських полигачів // Шлях колгоспника (Богуслав). 1932. 29 вересня, № 118. С. 2.

${ }^{16}$ Передовиків хлібозаготівлі премійовано (Постанова президії РВК від 10.11.32 р.) // Колгоспник Рокитнянщини (Рокитне). 1932. 18 листопада, № 105.
} 
протиставлення активу села й ударникам, які «з більшовицькою завзятістю боролися за хліб та мобілізацію коштів» ${ }^{17}$, «куркульським агентам», або ж «членам сільради, які стали до табору ворогів»: «Із 24 членів сільради [Антонівської] 3 зовсім виїхали з села, а 12 членів сільради: Чорнобров М., Пархоменко 0., Архипенко Ів., Пархоменко О., Сосновська Т., Згорда П., Замула А., Ходаківський В., Зворська П., Загниборода Ам., Звичайний К., Чорнобров А. зовсім відірвались від сільради. Здали позиції боротьби за хліб класовому ворогові. На кутках не працюють та ще й розкладають інший сільський актив. Глитайських прибічників, що зраджують інтересам трудящого селянства, треба негайно вивести з ради, а самих злісних притягнути до відповідальності» ${ }^{18}$. Про «погану» працю та «відверто ворожу роботу» на хлібозаготівлі членів Луб'янської сільради (Семен і Степан Киянищі, Максим Литвин) мовиться у номері згаданлї газети від 28 грудня 1932 р. Оскільки вони чинили спротив хлібозаготівлі пленум сільради вивів їх складу останньої як «ворогів народу» й ухвалив за «шкідницьку роботу» віддати до суду ${ }^{19}$.

«Куркулям», «куркульським прихвостням» і липовим активістам, згідно «морального кодексу» будівників комунізму, до яких відносили себе й так звані виконавці й уповноважені, протиставлялися «ударники». Такий хід був вагомим засобом ідеологічного впливу, що надихав у боротьбі за хліб комсомольців («Боротьба за хліб - бойовий іспит і права честі комсомолу» ${ }^{20}$ ) й піонерські загони, які активно долучалися до виконання планів хлібозаготівлі ${ }^{21}$. Водночас, на роботу комсомольських осередків нарікали секретарі райкомів ЛКСМУ. Керівники районних комсомольських осередків зазначали пасивність окремих сільських комсомольців, відсутність розуміння, що «хлібозаготівля $є$ найважливіша гос[ударственно]-політ[ична] кампанія». Також у номері за 11 грудня 1932 p. газети «За суцільну колективізацію» акцентувалася увага читачів на тому, що окремі комсомольці «зрослися» 3 куркулем і своєю бездіяльністю допомагали «зривати хлібозаготівлі». Подібні дії одразу засуджувалися, їм надавалася політична оцінка і таврувалося як «політична короткозорість». У замітках лунали заклики до перевірки сільських комсомольських осередків, проведення так званої «чистки» від політично неблагонадійних осіб ${ }^{22}$.

Усе це підтверджувало тезу про характерну для райкомів КП(б)У, райвиконкомів, місцевих апаратів ДПУ УСРР виразну фронтову риторику, що свідчить про войовниче налаштування влади до всіх тих, хто стоїть на заваді реалізації ії планів - вчинення геноциду українців. Хлібозаготівля стала одним із фронтів цієї війни, де вороги як селяниодноосібники, тавровані «куркулями», так і «куркульські елементи» у лавах армії активістів й уповноважених, що відмовлялися виконувати накази партійних структур, або ж неналежно чи неохоче їх виконували. Це голови колгоспів, члени райвиконкомів,

\footnotetext{
${ }^{17} 3$ більшовицькою завзятістю боролися за хліб та мобілізацію коштів. // Колгоспник Рокитнянщини (Рокитне). 1932. 7 грудня, № 110. С. 1.

${ }^{18}$ Члени сільради, стали до табору ворогів // Колгоспник Рокитнянщини (Рокитне). 1932. 21 грудня, № 114. С. 1.

${ }^{19}$ Так «працювали» куркульські агенти // Колгоспник Рокитнянщини (Рокитне). 1932. 28 грудня, № 116. С. 1.

${ }^{20}$ Комсомольці с. Радчики - приклад у боротьбі за хліб // За суцільну колективізацію (Тальне). 1932. № 143, 13 грудня. С. 1.

${ }^{21}$ Піонер-загін бореться за виконання планів хлібозаготівлі // За суцільну колективізацію (Тальне). 1932. № 146, 25 грудня. С. 1.

${ }^{22}$ Щоденне завдання кожному комсомольцю // За суцільну колективізацію (Тальне). 1932. № 141, 11 грудня. С. 1.
} 
бригадири, комсомольці й ін. Їхні дії кваліфікувалися як саботаж і «політичний злочин», тому вони разом з селянами-«куркулями» знаходилися поза законом.

На шпальтах чернігівських районних газет знаходимо подібну риторику. Все ті ж нарікання на неробство, диверсію та дезертирство з боку «куркульських агентів» і «полигачів». Кореспондент газети «Прапор комуни» (Бахмач) писав про уповноваженого та члена сільради, які не бажали працювати ${ }^{23}$, про саботаж хлібоздачі десятихатниками ${ }^{24} . \mathrm{y}$ газеті «За більшовицькі темпи» (Березна) наголошувалося на важливості самомобілізації сільського активу на завершення хлібозаготівлі, на особливій ролі ударних бригад ${ }^{25}$. На думку кореспондента, в їхній боротьбі із «куркулем» їм мав допомагати сільський i колгоспний актив - «батраки, бідняки й трудящі на передовій фронту хлібозаготівлі»: «Як і слід було сподіватися в своїй роботі бригади зустріли шалений опір куркуля. Куркулі Курдюк, Шиленко поховали були хліб, картоплю в ями. Разом 3 трудящим селянством, під проводом партійного осередку опір куркуля зламано» ${ }^{26}$.

Зрозуміло, що ті, хто стояли за заваді «трудящому селянству» виконувати хлібозаготівельний план, є ворогами радянської влади, але як бути з самим селянським активом, чи такий він вірний цій владі? Виявляється, як стало відомо з газет, чимало активістів відмовлялися та саботували виконання хлібозаготівлі. Ось лише низка заголовків тієї ж таки газети «За більшовицькі темпи»: «Голова КНС - куркульський агент» ${ }^{27}$ (оскільки він радив ховати хліб, щоб люди не померли від голоду); «Ганьба таким “активістам” як Кравченко»; «За дезорганізацію хлібозаготівельного фронту - Мищенко Любу»; «Політична короткозорість партосередків дає можливість пролазити до лав партії куркульським агентам - 3 лав комсомолу» ${ }^{28}$; «Дезертири хлібозаготівельного фронту» ${ }^{29}$.

Подібні інформації публікувалися на сторінках видання «За суцільну колективізацію» (Бобровиця) - «Викорінити благодушні настрої в хлібозаготівлях», «Актив злигався з куркульнею», «Учительство нехтує роботу на сотнях», «Ганебні наслідки "роботи” опортуніста Бондаря» ${ }^{30}$; «Допомагають куркулеві зривати хлібозаготівлі» ${ }^{31}$, «Самі "активісти”

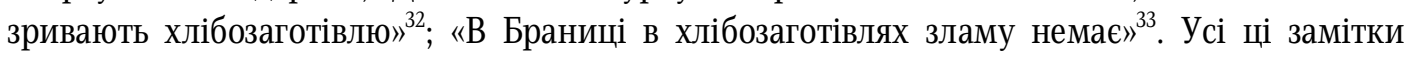

\footnotetext{
${ }^{23}$ Зривника хлібозаготівлі покарано // Прапор комуни (Бахмач). 1932. № 53. С. 2; Бердник - друг куркульства // Прапор комуни (Бахмач). 1932. № 64. С. 2.

${ }^{24}$ Потрібно більше рішучості від сільради; Башук допоміг куркулю Брагинцю поховати хліб // Прапор комуни (Бахмач). 1933. № 151. С. 1.

${ }^{25}$ Боротися за хліб по ударному // За більшовицькі темпи (Березна). 1932. № 101. С. 2.

${ }^{26}$ Батраки, бідняки й трудящі середняки Стільного стали в шереги передовиків на фронті хлібозаготівлі; Агентам куркулів, зривникам хлібозаготівлі - в органах пролетарської диктатури місця нема // За більшовицькі темпи (Березна). 1932. № 105. С. 1.

${ }^{27}$ Голова КНС - куркульський агент // За більшовицькі темпи (Березна). 1932. № 106. С. 1.

${ }^{28}$ Ганьба таким «активістам» як Кравченко; За дезорганізацію хлібозаготівельного фронту - Мищенко Любу; Політична короткозорість паросередків дає можливість пролазити до лав партії куркульським агентам - 3 лав комсомолу // За більшовицькі темпи (Березна). 1932. № 114. С. 1.

${ }^{29}$ Дезертири хлібозаготівельного фронту // За більшовицькі темпи (Березна). 1933. № 8. С. 1.

${ }^{30}$ Викорінити благодушні настрої в хлібозаготівлях; Актив злигався з куркульнею; Учительство нехтує роботу на сотнях; Ганебні наслідки «роботи» опортуніста Бондаря // За суцільну колективізацію (Бобровиця). 1932. № 21. C. 2.

${ }^{31}$ Допомагають куркулеві зривати хлібозаготівлі // За суцільну колективізацію (Бобровиця). 1932. № 95. С. 1.

${ }^{32}$ Самі «активісти» зривають хлібозаготівлю // За суцільну колективізацію (Бобровиця). 1932. № 118. С. 1.

${ }^{33}$ В Браниці в хлібозаготівлях зламу нема // За суцільну колективізацію (Бобровиця). 1932. № 121. С. 1.
} 
свідчать про приклади масової непокори та супротиву у лавах так званих «сільських активістів». Вони розуміли небезпеку масового голодування і категорично відмовлялися виконувати плани хлібозаготівлі, саботували повсякденну роботу щодо розорення селянських господарств. Також чимало заміток у районній пресі про відмову членів сільрад агітувати селян щодо здачі збіжжя, вони відверто говорили про нереальність виконання цих планів. Зокрема, кореспонденти писали про випадки переховування хліба на Глухівщині: «Є факти, коли окремі “активісти”, підпавши під вплив куркулів, переховують куркульський хліб. Підкуркульник Новообраний Павло, колишній член комісії сприяння хлібозаготівлям, приховав понад 60 пудів куркульського хліба» ${ }^{34}$. У відповідь на подібні ситуації - стягнення штрафів з господарств і розгортання широкої масової роботи на кутках серед одноосібників за цілковите виконання плану хлібозаготівлі.

Схожу ситуацію описали і на Буриныщині (Буринський район Сумської області), де комсомольці та сільські активісти не тільки уникали роботи на хлібозаготівлі, а й самі не відмовлялися здавати збіжжя ${ }^{35}$. Голову Миколаївської сільради Галайду дописувач ідентифікував як «куркульського агента 3 партійним квитком», адже він виступив на партійних зборах з промовою про те, що вивозити хліб не можна. Також він зумисне затримував вивезення 250 пудів хліба. Райком КП(б)У за таку зухвалість позбавив його членства у партії ${ }^{36}$.

За спроби не допустити масової загибелі селян таких осіб таврували «куркульськими агентами», «вовками в овечій шкурі», «лжеактивістами». Подібні політичні характеристики отримували комсомольці або сільські активісти, які відмовлялися працювати на хлібозаготівлі. Про це публікувалися замітки у газетах «Комунар» (Городня) $)^{37}$, «В соціалістичний наступ» (Добрянка) $)^{38}$, «Колгоспне життя» (Остер) ${ }^{39}$ й ін.

Важливим і поширеним прийомом боротьби з «куркульським елементом» було акцентування на персональних і локальних факторах. Так, на сторінках газет вказували прізвища та імена зразкових виконавців хлібозаготівлі, заохочуючи та преміюючи їх, а також прізвища тих, хто «зривав» і«перешкоджав» виконанню хлібозаготівельного плану. Приміром, у замітці «Рівнятися на бригаду тов. Нацика»у газеті «Розгорнутим фронтом» (Козелець) зазначалося: «Куркульські недобитки уперто саботують здавання хліба, продовжуючи його розбазарювати та ховати, водночас, скиглять перед сільрадою про свою неспроможність виконати хлібні плани. Сільрада же, не зважаючи на ці “сльози”, посилює наступ на куркулів, виявляючи їх шахрайство й застосовуючи до злісних нездавців заходи адмінвпливу. Особливу активність у боротьбі з класовим ворогом виявила виявила бригада Нацика Федора Андрійовича, що знайшли чималу кількість схованого від держави хліба» ${ }^{40}$.

\footnotetext{
${ }^{34}$ Нові маневри куркуля викрито // Колективіст Глухівщини (Глухів). 1933. № 8. С. 1.

${ }^{35}$ Чому у Дяківці на хлібозаготівельному фронті прорив? // Колективіст Буринщини (Буринь). 1932. № 109. С. 1; КСМ осередок артілі ім. Сталіна саботує хлібозаготівлі // Колективіст Буринщини (Буринь). 1932. № 112. С. 1.

${ }^{36}$ Куркульський агент з партійним квитком // Колективіст Буринщини (Буринь). 1932. № 118. С. 1.

${ }^{37}$ Дизертирів - із комсомолу // Комунар (Городня). 1932. № 190. С. 1.

${ }^{38}$ Ст-Ярилівські комсомольці на поводу в куркулів; Як хутір Зайців виходить із прориву // В соціалістичний наступ (Добрянка). 1932. № 141. С. 1.

${ }^{39}$ Вовчогірський комсомол осторонь хлібозаготівель; Руднянський комсомол саботує хлібозаготівлю // Колгоспне життя (Остер). 1932. №106. С. 1; Савинський комсомол за хліб не бореться // Колгоспне життя (Остер). 1932. № 112. С. 1.

${ }^{40}$ Працювати, як бригада т. Насона // В соціалістичний наступ (Добрянка). 1933. № 3. С. 1.
} 
У першому номері цього ж видання знаходимо замітку про голову сільради Пилипа Мегема, якого на виїзній сесії Козелецького нарсуду, враховуючи «революційні заслуги» (червоний партизан), було засуджено до 3 років позбавлення волі з висланням за межі УСРР на 5 років та з 2-х річною «поразкою в правах». Його обвинувачували у тому, що він «залишивши сільраду на час перепідготовки комскладу РСЧА, не здав справ сільради заступникові i, відбувши перепідготовку, до своїх обов'язків не приступив, незважаючи на неодноразові попередження з боку голови РВК тов. Йоненка та секретаря РПК тов. Пузиревського» ${ }^{41}$.

У замітці «В'язівчане показують приклад, як треба боротися за хліб» газети «Комуна» (Конотоп) йшлося про роботу бригад одноосібників-передовиків с. В'язове, які виконали річний план на 56\%, що є досить високим показником. Також вони «взяли на буксир відсталих одноосібників, допомагають їм цими ж днями вивершити річний план хлібозаготівлі, зокрема 3 продовольчих культур ${ }^{42}$. Кореспондент наполягав, що за прикладом в'язівчан повинні піти усі партійні, комсомольські осередки, колгоспи та сільради у межах соціалістичного змагання за краще і швидке виконання планів хлібозаготівлі. Якщо деякі передовики хлібозаготівельного фронту працювали досить успішно, за що преміюються (як у випадку з Ніжинщиною, де 25 січня 1932 р. були премійовані на 100, 75 і 50 крб. секретарі партійних осередків, голови та секретарі сільрад, голови виробничих товариств ${ }^{43}$ ), то досвід багатьох бригад визначається як «відсталий» ${ }^{44}$, такий, що «зриває» і «саботує» хлібозаготівлі ${ }^{45}$. Тому потрібно очистити актив від саботажників і дезертирів, заплямувати ïx ганьбою, взявши за зразок боротьби за хліб лише тих, хто чітко виконує вказівки партійного керівництва (замітки на кшталт «Рівнятися на десятихатника Кузьменка Івана» ${ }^{46}$, «Бригада 3 честю виконала своєї завдання» ${ }^{47}$, «Шалімівський актив бореться за хліб» ${ }^{48}$, «Рівнятися на бригаду Романівського кутка» ${ }^{49}$ й ін.).

I подібними акцентуваннями, коли апелюють до прізвищ, окремих бригад і селищ, переповнені сторінки районної періодики не лише Київщини та Чернігівщини, але й інших областей радянської України.

У статті про вбивство активіста І. Горбача чітко сформульована суть загрози «куркулів» і «куркульського елементу» для активістів та уповноважених: «Пролетаріат і колгоспне селянство країни рад ліквідують рештки капіталізму. Куркуля ліквідуємо як клас на базі суцільної колективізації. Класовий ворог відчуває свою неминучу загибель, ставить опір, намагається різними методами шкодити розвиткові соціалістичного будівництва. Починаючи з набріхувань на радянську владу, розпускання невірних чуток серед

\footnotetext{
${ }^{41}$ Дезертирові 3 хлібного фронту, зраднику партії - Мегему суворе покарання // Розгорнутим фронтом (Козелець). 1933. № 1. С. 2.

${ }^{42}$ В’язівчане показують приклад, як треба боротися за хліб // Комуна (Конотоп). 1932. № 126. С. 1.

${ }^{43}$ Передовиків хлібозаготівельного фронту - премійовано // Нове село (Ніжин). 1932. №12. С. 1.

${ }^{44}$ Досвід передових бригад - відсталим // Комуна (Конотоп). 1932. № 154. С. 1.

45 Зривщиків, саботажників хлібозаготівель - до права; Суворо карати зривачів; Це не борці за хліб - за соціялізм // Колгоспне життя (Остер). 1932. № 105. С. 1; Савинський комсомол за хліб не бореться // Колгоспне життя (Остер). 1932. № 112. С. 1; Вовчогірський комсомол осторонь хлібозаготівель; Руднянський комсомол саботує хлібозаготівлю // Колгоспне життя (Остер). 1932. № 106. С. 1.

${ }^{46}$ Рівнятися на десятихатника Кузьменка Івана // Соціялістичне життя (Понорниця). 1933. № 79. С. 1.

${ }^{47}$ Бригада з честю виконала своє завдання // Конопляр С-Будщини (Середина-Буда). 1932. № 79. С. 1.

${ }^{48}$ Шалимівський актив бореться за хліб // Конопляр С-Будщини (Середина-Буда). 1932. № 107. С. 2.

${ }^{49}$ Рівнятись на бригаду Романівського кутка // Більшовицькі темпи (Талалаївка). 1933. № 13. С. 1.
} 
населення, дискредитації окремих представників органів радвлади та кінчаючи організацією терористичних актів - ось у чому полягає боротьба, ось у чому полягають методи класового ворога у боротьбі проти диктатури пролетаріату» ${ }^{50}$.

Також на сторінках районної преси Київщини та Чернігівщини періоду Голодоморугеноциду 1932-1933 рр. можна зустріти свідчення опору селянства такій репресивній політиці хлібозаготівлі. Приміром, висвітлюються випадки нападів на голів сільради на Корюківщині - одного поранено і двох вбито ${ }^{51}$, та антихлібозаготівельної агітації із закликами «брати вила й колоти тих, хто везе хліб» ${ }^{52}$. Розглядаються ситуації, коли селяни підпалили хату активіста та зі зброєю не давали загасити пожежу ${ }^{53}$, чи забили до смерті активіста, який брав участь у конфіскаціях збіжжя у селянських господарствах ${ }^{54}$, чи пострілом через вікно вбили активіста, який стягував державну позику ${ }^{55}$, чи вбили голову колгоспу пострілом з рушниці у голову під час роботи на кутку ${ }^{56}$, чи застрелили із втинка міліціонера й активіста під час виконання плану хлібозаготівлі ${ }^{57}$, чи в ході вилучення бригадою хліба селянин дерев'яною качалкою звалив з ніг і розбив до крові голову бригадира ${ }^{58}$ й інші обставини.

На Київщини районна преса також фіксувала численні випадки супротиву насильницькій хлібозаготівлі. Так, у Богуславі переслідували й обстріляли бригадира, спалили хату колгоспника ${ }^{59}$, чинили організований груповий опір (помста більшовицьким активістам, вчиняли підпали, проводили антирадянську агітацію, вступали у збройні сутички 3 міліцією $)^{60}$, чинили супротив опису майна за невиконання хлібозаготівель ${ }^{61}$; у Білій Церкві селянин побив членів бригади, які вилучали у нього хліб ${ }^{62}$, а у Таращі в ямах для зберігання хліба виявили зброю ${ }^{63}$.

Всі факти спротиву кваліфікувалися уповноваженими 3 хлібозаготівлі як «куркульський терор». Традиційно із часів «червоного терору» лунало гасло: «На терор класового ворога відповімо розпаленням жагучої ненависті до гидких ненависних недобитків класового ворога, вивершенням плану сівби якісно й на строк. Радянська громадські вимагає найвищої міри покарання затриманим куркулям-терористам. Ще

\footnotetext{
${ }^{50}$ Вбито тов. Горбача І.С. // Більшовицький шлях (Корюківка). 1932. № 72, 21 липня.

${ }^{51}$ Ibidem.

52 Дати відсіч // Колективіст Буринщини (Буринь). 1932. № 88, 18 вересня.

${ }^{53}$ Класовий ворог ножем та підпалом чинить опір хлібозаготівлі // Колгоспне життя (Остер). 1932. № 8, 20 січня.

54 Жертва куркульської помсти // Поліський комунар (Короп). 1932. № 83, 24 листопада.

${ }^{55}$ На вбивство т. Піддячого відповісти новою хвилею піднесення ударництва // Соціалістичне село (Мала Дівиця). 1932. № 62,26 липня.

${ }^{56}$ Тов. Хвоста - кращого голову колгоспу забито знахабнілим класовим ворогом бандитом куркулем // За соціалістичне полісся (Ріпки). 1933. № 3, 19 травня.

${ }^{57}$ На постріл класового ворога - відповідаймо ще більшим згуртуванням трудящих навколо партії // За суцільну колективізацію (Бобровиця). 1933. № 4, 24 січня.

${ }_{58}^{5}$ Куркулів-саботажників хлібозаготівлі покарано // Колгоспник Дмитрівщини (Дмитрівка). 1933. № 7, 19 січня.

${ }^{59}$ На ворожі вилазки куркулів та підкуркульників відповімо 100 відс. закінченням планів хлібозаготівлі // Шлях колгоспника (Богуслав). 1931. № 104, 21 жовтня.

${ }^{60}$ Сухомлинівці - клясові вороги трудящих зазнали нещадної поразки // Шлях колгоспника (Богуслав). 1932. №7, 16 січня

${ }^{61}$ Куркульська помста // Шлях колгоспника (Богуслав). 1932. № 8, 18 січня

${ }^{62}$ Хліб державі // Радянська нива (Біла Церква). 1932. №12, 27 січня.

${ }^{63}$ У ямах крім хліба ще й зброя // Голос колгоспника (Тараща). 1933. № 4, 22 січня.
} 
тісніше згуртуймо свої лави навколо комуністичної партії, давши остаточний бій недобиткам класового ворога, домогтися нових перемог по успішному закінченню сівби та завершенню суцільної колективізації...»" ${ }^{64}$.

Таким чином, періодика Київщини та Чернігівщини 1932-1933 рр. свідчить про масштаби та динаміку застосування більшовицькою владою своїх репресивних технологій стосовно до українського селянина-власника під час виконання злочинного хлібозаготівельного плану. Одним із головних, і як виявилося доволі ефективних, інструментів політтехнології комуністичного режиму, були групи сільських активістів та уповноважених, які вдавалися до цілого арсеналу методів у боротьбі з куркулями та «куркульським елементом», виконуючи злочинні норми хлібозаготівлі. Усе це підтверджувало тезу про характерну для райкомів КП(б)У, райвиконкомів і місцевих органів ДПУ УСРР виразну фронтову риторику, що свідчить про войовниче налаштування комуністичної влади до всіх тих, хто заважав реалізації її плану - вчинення геноциду українців.

Штучний образ ворога - «куркуля», що накладався у межах масової пропагандистської кампанії на селян-власників, що важко працювали на землі й не хотіли віддавати напрацьоване, активно впроваджувався у масову свідомість населення республіки. Маніпулюючи фактами, районні газети, комуністичні пропагандисти підводили основу для безумовної конфіскації збіжжя, майна цієї категорії українських селян. Комуністична влада намагалася позбавити їх економічної основи для спротиву суцільної колективізації, масової «пролетарізації» українського селянства.

Паралельно місцева преса розкручувала тезу про існування «підкуркульників», «куркульського елементу» і числа сільської та колгоспної адміністрації, сільського активу та уповноважених. Розуміючи згубність масштабів хлібозаготівлі», ці особи намагалися зберегти невелику частину збіжжя для запобігання масової смертності від голоду або відмовлялася працювати у бригадах по вилученню продовольства та майна у селянських господарствах. Їхні дії у пропагандистських матеріалах місцева комуністична адміністрація кваліфікувала як «зрадництво», «саботаж», «дезертирство». Також вони ідентифікувалися як «полигач», «поплічник куркулів», «підкуркульник», які підлягали громадському осуду, вилученню з партії та засудженню до позбавлення волі. Вище політичне керівництво СРСР їхні дії вважало за «політичний злочин», а тому вони разом з «селянами-куркулями» знаходилися поза законом.

Водночас, партійні структури, використовуючи районну періодику, прямо вказували й виявляли подібних «куркульських агентів з партійними квитками», на базі методу акцентування на персональних і локальних факторах, протиставляючи їм «ударні» елементи, до яких відносили окремі постаті, бригади та села, які виконували та перевиконували хлібозаготівлі. Як бачимо, ці хлібозаготівлі були справжньою «боротьбою за хліб», полем бойових дій, де активісти й виконавці були бойовими одиницями комуністичного режиму, а газети - важливою зброєю та знаряддям масової пропаганди й осквернення українського селянина, що відіграла важливу роль у вчинені злочину Голодомору-геноциду 1932-1933 рр. в Україні.

\footnotetext{
${ }^{64}$ Жертва куркульської помсти // Поліський комунар (Короп). 1933. № 51, 19 травня. С. 2.
} 


\title{
The Activity of the Authorized Persons and Activists During the Organization of the Holodomor-Genocide in Kyiv and Chernihiv Regions in 1932-1933
}

\begin{abstract}
The aim of the study is to analyze the examples of the struggle of the activists and grain procurement authorized persons with «kurkuls' element» during the Holodomor genocide of 1932-1933 in Kyiv and Chernihiv regions. The materials of local press of these years were used. Methodology is based on the principles of historicism, objectivity, and systematics. The methods of source study of periodicals, as well as the general historical methods (historical genetical, retrospective, historical typological) were used. Scientific novelty. On the basis of a wide spectrum of materials from the press, the destructive role of the activists and authorized persons in struggle with the «kurkuls' element» during the grain procurements, which led to the Holodomor genocide in the given regions, was argued.

Conclusion. It was mentioned that one of the main and, as it was found, quite effective instruments of the political technology of the communist totalitarian regime, were the groups of village «activists», perpetrators and authorized persons. They used a wide arsenal of methods to combat the «kurkuls» and «kurkuls' element» while implementing the criminal norms of grain procurement. When the situation with «kurkuls» was understandable - it was absolutely artificial image of enemy, which was used in relation to the farmers during the mass propaganda campaign, the situation with so called «kurkuls' element» is much more interesting. The communist regime included traitors, saboteurs and deserters from among the village activists who refused to comply with the criminal rules of grain procurement into this group. They were identified as «henchmen» and «kurkuls» allies, which are subject to public condemnation, expulsion from the party and sentencing to different terms of imprisonment depending on the degree of guilt. It was found that the communist regime, using the district press, directly pointed out and identified such «kurkuls' agents with party tickets», based on the method of emphasizing personal and local factors, contrasting them with "udarnik» elements, which included individuals, brigades and villages that fulfilled and overfulfilled grain procurement.
\end{abstract}

Keywords: Holodomor genocide of 1932-1933, district periodicals, activists, authorized persons, grain procurements 